\title{
IMPLEMENTASI PENDIDIKAN KARAKTER DALAM \\ PEMBELAJARAN MATEMATIKA MELALUI PENDEKATAN KONSTEKTUAL
}

\author{
Oleh: Suci Yuniati \\ Prodi Pendidikan Matematika Fakultas Tarbiyah dan Keguruan UIN Suska Riau \\ e-mail: suciyuniatimlg@yahoo.co.id
}

\begin{abstract}
Abstrak:
Pembentukan karakter siswa sesungguhnya sudah tertuang dalam fungsi dan tujuan pendidikan nasional, namun fungsi dan tujuan pendidikan nasional seolah-seolah gagal dilaksanakan. Salah satu gagalnya penerapan tujuan dan fungsi pendidikan nasional dapat dilihat dari kondisi pendidikan di sekolah saat ini yang cenderung mengembangkan aspek kognitif siswa, dimana aspek selain kognitif seperti afektif kurang mendapat perhatian. Hal ini menyebabkan rendahnya karakter positif siswa yang menyebabkan adanya tawuran antar siswa, penggunaan narkoba, pergaulan bebas, penuturan bahasa yang buruk, tidak santun, suka melangkar aturan, egois, pornografi yang terjadi dikalangan siswa, dan lain sebagainya. Melihat fenomena tersebut di atas maka perlu adanya penerapan pendidikan karakter, pendidikan karakter di sekolah dapat dikembangkan melalui pengalaman belajar dan proses pembelajaran yang bermuara pada pembentukan karakter dalam diri siswa. Pendidikan karakter dalam kegiatan belajar mengajar di kelas, dilaksanakan menggunakan pendekatan terintegrasi dalam semua mata pelajaran. Pendidikan karakter diberikan secara terpadu melalui pengenalan nilai-nilai, fasilitas kesadaran akan pentingnya nilai-nilai, dan penginternalisasian nilai-nilai kedalam tingkah laku siswa sehari-hari, baik di dalam maupun di luar kelas. Pada dasarnya kegiatan pembelajaran matematika, selain menjadikan siswa menguasai kompetensi (materi) yang ditargetkan, juga dirancang untuk menjadikan siswa mengenal, menyadari/peduli, dan menginternalisasi nilai-nilai dan menjadikan perilaku. Nilai-nilai karakter yang dapat dikembangkan adalah berfikir kritis dan logis, rasa ingin tahu, toleransi, bertanggung jawab, mandiri, kreatif, jujur, menghargai karya dan prestasi orang lain, dan disiplin. Kegiatan pembelajaran matematika dalam kerangka pengembangan karakter siswa dapat menggunakan berbagai pendekatan. Diantaranya pendekatan kontekstual sebagai konsep belajar dan mengajar yang membantu guru dan siswa mengaitkan antara materi yang diajarkan, dengan situasi dunia nyata. Sehingga, siswa mampu untuk membuat hubungan antara pengetahuan yang dimilikinya dengan penerapannya dalam kehidupan siswa. Dengan begitu, siswa memiliki hasil yang komprehensif tidak hanya pada tataran "kognitif" tetapi pada tataran afektif serta psikomotor.
\end{abstract}

Kata Kunci: Pendidikan Karakter, Pendekatan Kontekstual. 


\section{Pendahuluan}

Dahulu Bangsa Indonesia dikenal berkarakter positif seperti ramah-tamah, lemah lembut, berbudi pekerti luhur, sopan santun, jujur, dan cinta tanah air. Perubahan zaman serba teknologi canggih karakter positif tersebut perlahanlahan mulai ditinggalkan. Masyarakat yang terbiasa ramah tamah, santun berperilaku, melaksanakan musyawarah mufakat dalam menyelesaikan masalah, bersikap toleran serta gotong royong cenderung berubah berkarakter negatif seperti kekerasan dan kerusuhan, pergaulan bebas, korupsi yang merambah pada semua sektor kehidupan masyarakat, anarkis, penuturan bahasa yang buruk, tidak santun, narkoba, suka melangkar aturan, egois, pornografi dikalangan remaja, dan lain sebagainya. Apabila suatu bangsa sudah tidak memiliki karakter yang tangguh, maka perlu segera dicari cara mengembalikannya. Dalam mengembalikan karakter positif diperlukan usaha menyeluruh dari semua pihak yaitu keluarga, masyarakat, dan sekolah (Sulistyowati, 2012).

Pembentukan karakter siswa sesungguhnya sudah tertuang dalam fungsi dan tujuan pendidikan nasional yaitu "Pendidikan nasional berfungsi mengembangkan dan membentuk watak serta peradapan bangsa yang bermartabat dalam rangka mencerdaskan kehidupan bangsa, bertujuan untuk berkembangnya potensi siswa agar menjadi manusia yang beriman dan bertakwa kepada Tuhan Yang Maha Esa, berakhlak mulia, sehat, berilmu, cakap, kreatif, mandiri, dan menjadi warga negara yang demokratis serta bertanggung jawab" (Undang-undang Republik Indonesia No.20 Tahun 2003 tentang Sistem Pendidikan Nasional). Namun permasalahan di lapangan, fungsi dan tujuan pendidikan nasional itu seolah-seolah gagal dilaksanakan. Salah satu gagalnya penerapan tujuan dan fungsi pendidikan nasional dapat dilihat dari kondisi pendidikan di sekolah saat ini yang cenderung mengembangkan aspek kognitif siswa, dimana aspek selain kognitif seperti afektif kurang mendapat perhatian. Guru hanya mengejar bagaimana hasil belajar siswa meningkat mulai dari hasil ulangan harian sampai hasil Ujian Nasional (UN) siswa. Kebanyakan guru dan Kepala Sekolah berprinsip, apabila sekolah yang dipimpinnya banyak siswa yang tidak lulus Ujian Nasional (UN), akan menjadi suatu 
musibah dan permasalahan yang sangat "memalukan". Maka dari itu, pihak sekolah melakukan berbagai cara agar siswanya bisa lulus "100\%". Hal ini disebabkan oleh sistem pendidikan yang lebih berorientasi pada mengejar target kurikulum, bahkan terkadang guru menunjukan sikap yang negatif terhadap pembentukan karakter siswa. Sebagai contoh, di media televisi pada tanggal 4 Maret 2013 diberitakan bahwa "seorang Wakil Kepala Sekolah melakukan pelecehan seksual kepada siswinya" dan guru melakukan pemukulan kepada siswanya sehingga siswa tersebut tidak berani datang ke sekolah. Selain itu, guru kurang menghargai dan lebih banyak mengkritik hasil pekerjaan siswa. Akibatnya siswa menjadi kurang percaya diri, kurang menghargai orang lain, dan tidak kreatif.

Implementasi pendidikan karakter di sekolah dikembangkan melalui pengalaman belajar dan proses pembelajaran yang bermuara pada pembentukan karakter dalam diri siswa. Pendidikan karakter dalam kegiatan belajar mengajar di kelas, dilaksanakan menggunakan pendekatan terintegrasi dalam semua mata pelajaran (Sulistyowati, 2012). Pendidikan karakter diberikan secara terpadu melalui pengenalan nilai-nilai, fasilitas kesadaran akan pentingnya nilai-nilai, dan penginternalisasian nilai-nilai kedalam tingkah laku siswa sehari-hari, baik di dalam maupun di luar kelas.

Nilai-nilai karakter yang dapat dikembangkan adalah berfikir kritis dan logis, rasa ingin tahu, toleransi, bertanggung jawab, mandiri, kreatif, jujur, menghargai karya dan prestasi orang lain, dan disiplin. Menurut Sulistyowati (2012) kegiatan pembelajaran matematika dalam kerangka pengembangan karakter siswa dapat menggunakan berbagai pendekatan. Diantaranya pendekatan kontekstual sebagai konsep belajar dan mengajar yang membantu guru dan siswa mengaitkan antara materi yang diajarkan, dengan situasi dunia nyata (Nurhadi, 2004). Sehingga, siswa mampu membuat hubungan antara pengetahuan yang dimilikinya dengan penerapannya dalam kehidupan siswa.

\section{Pembahasan}

\section{A. Pendidikan Karakter}

Karakter adalah respon langsung yang dilakukan seseorang terhadap setiap stimulus yang datang dalam keadaan sadar, kata karakter itu sendiri berasal dari bahasa 
yunani yaitu "caracteer" yang artinya tanda, ciri atau gambaran yang diukir (Bukit, 2012). Gordon Allport (Sulistyowati, 2012) mendefinisikan karakter manusia sebagai kumpulan atau kristalisasi dari kebiasan-kebiasan seorang individu. Sedangkan Chaplin (Sulistyowati, 2012) mendefinisikannya sebagai kualitas kepribadian yang berulang secara tetap dalam seseorang individu. Menurut Musfiroh (Sulistyowati, 2012) karakter mengacu kepada serangkaian sikap, perilaku, motivasi, dan keterampilan. Secara umum karakter berkaitan dengan pendidikan yang merupakan pendidikan yang mengembangkan nilai-nilai budaya dan karakter bangsa pada diri siswa.

Menurut Bukit (2012) fungsi pendidikan karakter adalah sebagai: 1) pengembangan yaitu pengembangan potensi siswa untuk menjadi pribadi berperilaku baik, 2) perbaikan yaitu memperkuat kiprah pendidikan nasional untuk bertanggung jawab dalam pengembangan potensi siswa yang lebih bermartabat, dan 3) penyaring yaitu untuk menyaring budaya bangsa sendiri dan budaya bangsa lain yang tidak sesuai dengan nilai-nilai budaya dan karakter bangsa yang bermartabat. Sedangkan tujuan pendidikan karakter adalah untuk: 1) mengembangkan potensi afektif siswa sebagai manusia dan warganegara yang memiliki nilai-nilai budaya dan karakter bangsa, 2) mengembangkan kebiasaan dan perilaku siswa yang terpuji dan sejalan dengan nilai-nilai universal dan tradisi budaya bangsa yang religius, 3) menanamkan jiwa kepemimpinan dan tanggung jawab siswa sebagai generasi penerus bangsa, 4) mengembangkan kemampuan siswa menjadi manusia yang mandiri, kreatif, berwawasan kebangsaan, dan 5) mengembangkan lingkungan kehidupan sekolah sebagai lingkungan belajar yang aman, jujur, penuh kreativitas dan persahabatan, serta dengan rasa kebangsaan yang tinggi dan penuh kekuatan.

Implementasi nilai-nilai pendidikan karakter

dilaksanakan melalui proses pemberdayaan dan pembudayaan sebagaimana digariskan sebagai salah satu prinsip penyelengaraan pendidikan nasional. Proses ini berlangsung dalam tiga pilar pendidikan yaitu: dalam 1) sekolah, implementasi pendidikan karakter di sekolah dikembangkan melalui pengalaman belajar dan proses pembelajaran yang bermuara pada pembentukan karakter 
dalam diri siswa. Pendidikan karakter dalam kegiatan belajar mengajar di kelas, dilaksanakan menggunakan pendekatan terintegrasi dalam semua mata pelajaran. 2) keluarga, keluarga merupakan hal yang terpenting dalam pembentukan karakter anak. Karena keluarga ibarat akar yang menentukan akan menjadi apa dan bagaimana seorang individu tersebut. Bila keluarga menjalankan fungsinya dengan baik, maka individu-individu yang dilahirkan akan mempunyai moral dan karakter yang baik, sehingga dapat membentuk sumber daya manusia yang berkualitas. 3) masyarakat, pembudayaan di masyarakat dapat dilakukan melalui keteladanan tokoh masyarakat, pembiasaan nilai-nilai di lingkungan masyarakat, pembinaan pengembangan hubungan dengan Tuhan Yang Maha Esa, penegakan aturan yang berlaku (Sulistowati, 2012).

Nilai-nilai yang dikembangkan dalam pendidikan budaya dan karakter bangsa diidentifikasi dari sumber-sumber sebagai berikut yaitu: agama, pancasila, budaya, dan tujuan pendidikan nasional. Berdasarkan keempat sumber nilai di atas, teridentifikasi sejumlah nilai untuk pendidikan dan karakter bangsa yang disajikan pada tabel 1 berikut ini:

Tabel 1. Deskripsi Nilai Pendidikan Budaya dan Karakter Bangsa

\begin{tabular}{|l|l|}
\hline \multicolumn{1}{|c|}{ Nilai } & \multicolumn{1}{|c|}{ Deskripsi } \\
\hline 1. Religius & $\begin{array}{l}\text { Sikap dan perilaku yang patuh dalam } \\
\text { melaksanakan ajaran agama yang dianutnya, } \\
\text { toleran terhadap pelaksanaan ibadah agama lain, } \\
\text { dan hidup rukun dengan pemeluk agama lain. }\end{array}$ \\
\hline 2. Jujur & $\begin{array}{l}\text { Perilaku yang didasarkan pada upaya menjadikan } \\
\text { dirinya sebagai orang yang selalu dapat dipercaya } \\
\text { dalam perkataan, tindahkan, dan pekerjaan. }\end{array}$ \\
\hline 3. Toleransi & $\begin{array}{l}\text { Sikap dan tindakan yang menghargai perbedaan } \\
\text { agama, suku, etnis, pendapat, sikap, dan tindakan } \\
\text { orang lain yang berbeda dari dirinya. }\end{array}$ \\
\hline 4. Disiplin & $\begin{array}{l}\text { Tindakan yang menunjukan perilaku tertib dan } \\
\text { patuh pada berbagai ketentuan dan peraturan. }\end{array}$ \\
\hline 5. Kerja Keras & $\begin{array}{l}\text { Perilaku yang menunjukan upaya sungguh- } \\
\text { sungguh dalam mengatasi berbagai hambatan } \\
\text { belajar dan tugas, serta menyelesaikan tugas } \\
\text { dengan sebaik-baiknya. }\end{array}$ \\
\hline 6. Kreatif & $\begin{array}{l}\text { Berpikir dan melakukan sesuatu untuk } \\
\text { menghasilkan cara atau hasil baru dari sesuatu }\end{array}$ \\
\hline
\end{tabular}




\begin{tabular}{|c|c|}
\hline & yang telah dimiliki. \\
\hline 7. Mandiri & $\begin{array}{l}\text { Sikap dan perilaku yang tidak mudah tergantung } \\
\text { pada orang lain dalam menyelesaikan tugas-tugas }\end{array}$ \\
\hline 8. Demokratis & $\begin{array}{l}\text { Cara berpikir, bersikap, dan bertindak yang } \\
\text { menilai sama hak dan kewajiban dirinya dan orang } \\
\text { lain. }\end{array}$ \\
\hline $\begin{array}{l}\text { 9. Rasa ingin } \\
\text { tahu }\end{array}$ & $\begin{array}{l}\text { Sikap dan tindakan yang selalu berupaya untuk } \\
\text { mengetahui lebih mendalam dan meluas dari } \\
\text { sesuatu yang dipelajarinya, dilihat, dan didengar. }\end{array}$ \\
\hline $\begin{array}{l}\text { 10. Semangat } \\
\text { kebangsaa } \\
n\end{array}$ & $\begin{array}{l}\text { Cara berpikir, bertindak, dan berwawasan yang } \\
\text { menempatkan kepentingan bangsa dan negara } \\
\text { diatas kepentingan diri dan kelompoknya. }\end{array}$ \\
\hline $\begin{array}{l}\text { 11. Cinta tanah } \\
\text { air }\end{array}$ & $\begin{array}{l}\text { Car berpikir, bersikap, dan berbuat yang } \\
\text { menunjukan kesetiaan, kepedulian, dan } \\
\text { penghargaan yang tinggi terhadap bahasa, } \\
\text { lingkungan fisik, sosial, budaya, ekonomi, dan } \\
\text { politik bangsa. }\end{array}$ \\
\hline $\begin{array}{l}\text { 12. Menghargai } \\
\text { prestasi }\end{array}$ & $\begin{array}{l}\text { Sikap dan tindakan yang mendorong dirinya untuk } \\
\text { menghasilkan sesuatu yang berguna bagi } \\
\text { masyarakat, mengakui, serta menghormati } \\
\text { keberhasilan orang lain. }\end{array}$ \\
\hline $\begin{array}{l}\text { 13. Bersahabat/ } \\
\text { komunikatif }\end{array}$ & $\begin{array}{l}\text { Tindakan yang memperlihatkan rasa senang } \\
\text { berbicara, bergaul, dan bekerja sama dengan } \\
\text { orang lain. }\end{array}$ \\
\hline 14. Cinta damai & $\begin{array}{l}\text { Sikap, perkataan, dan tindakan yang } \\
\text { menyebabkan orang lain merasa senang dan } \\
\text { aman atas dirinya }\end{array}$ \\
\hline $\begin{array}{l}\text { 15. Gemar } \\
\text { membaca }\end{array}$ & $\begin{array}{l}\text { Kebiasaan menyediakan waktu untuk membaca } \\
\text { bacaan yang memberikan kebijakan bagi dirinya. }\end{array}$ \\
\hline $\begin{array}{l}\text { 16. Peduli } \\
\text { lingkungan }\end{array}$ & $\begin{array}{l}\text { Sikap \& tindakan yang selalu berupaya mencegah } \\
\text { kerusakan pada lingkungan alam di sekitarnya, } \\
\text { dan pengembangan upaya-upaya untuk } \\
\text { memperbaiki kerusakan alam yang sudah terjadi }\end{array}$ \\
\hline $\begin{array}{l}\text { 17. Peduli } \\
\text { sosial }\end{array}$ & $\begin{array}{l}\text { Sikap dan tindakan yang selalu ingin memberi } \\
\text { bantuan pada orang lain dan masyarakat yang } \\
\text { membutuhkan. }\end{array}$ \\
\hline $\begin{array}{l}\text { 18. Tanggung } \\
\text { jawab }\end{array}$ & $\begin{array}{l}\text { Sikap dan perilaku seseorang untuk } \\
\text { melaksanakan tugas dan kewajibannya, yang } \\
\text { seharusnya dia lakukan, terhadap diri sendiri, } \\
\text { masyarakat, lingkungan (alam, sosial dan } \\
\text { budaya), negara dan Tuhan Yang Maha Esa. }\end{array}$ \\
\hline
\end{tabular}

(Kementerian Pendidikan Nasional, 2012). 
Sekolah dan guru dapat menambah ataupun mengurangi nilai-nilai tersebut sesuai dengan kebutuhan masyarakat yang dilayani sekolah dan hakikat standar kompetensi/kompetansi dasar dan materi bahasan suatu mata pelajaran. Menurut Budimarsyah (2011) ada enam nilai yang diharapkan menjadi nilai minimal yang dikembangkan di setiap sekolah yaitu jujur dan bertanggung jawab, cerdas, kreatif, tangguh, dan peduli.

Berdasarkan informasi di atas, maka pendidikan karakter adalah pendidikan yang mengembangkan nilai-nilai budaya dan karakter bangsa kepada siswa, sehingga siswa dapat memiliki dan menerapkan nilai-nilai tersebut dalam kehidupan sehari-hari agar menjadi manusia yang religius, produktif, dan kreatif.

\section{B. Pendekatan Kontekstual}

Pembelajaran kontekstual (Contextual Teaching and Learning-CTL) adalah konsep belajar yang mendorong guru untuk menghubungkan antara materi yang diajarkan dengan situasi nyata siswa dan mendorong siswa membuat hubungan antara pengetahuan yang dimilikinya dan penerapannya dalam kehidupan mereka. Pengetahuan dan keterampilan siswa diperoleh dari usaha siswa mengkontuksi sendiri pengetahuan dan keterampilan baru ketika mereka belajar (Nurhadi, 2004). Kontekstual merupakan strategi belajar yang tidak mengharuskan siswa menghafal fakta-fakta, tetapi sebuah strategi yang mendorong siswa mengkonstruksikan pengetahuan dibenak mereka sendiri. Melalui strategi CLT siswa diharapkan belajar melalui "mengalami", bukan "menghafal".

Dalam pembelajaran CTL melibatkan tujuh komponen yaitu: (Nurhadi, 2009)

1. Konstruktivisme (constructivism)

Konstruktivisme (constructivism) merupakan landasan berpikir atau filosofi model pembelajaran konstektual, yaitu pengetahuan dibangun manusia sedikit demi sedikit, yang hasilnya diperluas melalui konteks yang terbatas atau sempit dan tidak secara tiba-tiba. Pengetahuan bukanlah seperangkat fakta-fakta, konsep, atau kaidah yang siap untuk diambil dan diingat. Tetapi manusia harus mengkonstruksi pengetahuan itu dan memberi makna melalui pengalaman nyata. Siswa perlu dibiasakan untuk memecahkan masalah, menemukan sesuatu yang berguna 
bagi dirinya, dan bergelut dengan ide-ide yaitu siswa harus mengkonstruksikan pengetahuannya sendiri.

Esensi dari teori konstruktivisme adalah ide bahwa siswa harus menemukan dan mentranformasikan suatu informasi kompleks ke situasi lain, dan apabila dikehendaki informasi ini menjadi milik mereka sendiri. Berdasarkan hal ini, maka pembelajaran harus dikemas menjadi proses mengkonstruksi bukan menerima pengetahuan.

2. Bertanya (questioning)

Pengetahuan yang dimiliki oleh seseorang, selalu bermula dari bertanya, karena bertanya merupakan strategi utama dalam pembelajaran yang berbasis konstektual. Dalam pembelajaran yang produktif, kegiatan bertanya berguna untuk 1) menggali informasi, baik administrasi maupun akademik, 2) mengecek pemahaman siswa, 3) membangkitkan respon kepada siswa, 4) mengetahui sejauh mana keingintahuan siswa, 5) mengetahui hal-hal yang sudah diketahui siswa, 6) memfokuskan perhatian siswa pada sesuatu yang dikehendaki guru, 7) untuk membangkitkan lebih banyak lagi pertanyaan dari siswa, dan 8) untuk menyegarkan kembali pengetahuan siswa.

3. Menemukan (inquiry)

Menemukan merupakan bagian inti dari kegiatan strategi pembelajaran kontekstual. Pengetahuan dan keterampilan yang diperoleh siswa diharapkan bukan hasil mengingat seperangkat fakta-fakta, tetapi hasil dari menemukan sendiri. Guru harus selalu merancang kegiatan yang merujuk pada kegiatan menemukan, apapun materi yang diajarakan. Siklus inquiry adalah 1) observasi (observation), 2) bertanya (questioning), 3) mengajukan dugaan (hepothesis), 4) pengumpulan data (data gathering), dan 5) penyimpulan (conclusion). Adapun langkah-langkah kegiatan menemukan sendiri adalah 1) merumuskan masalah, 2) melakukan observasi, 3) menganalisis dan menyajikan hasil dalam tulisan, gambar, laporan, bagan, tabel, dan karya lainnya, dan 4) mengkomunikasikan atau menyajikan hasil karya pada pembaca, teman sekelas, guru dan audiens lainnya.

4. Masyarakat belajar (learning community)

Konsep masyarakat belajar menyarankan agar hasil pembelajaran diperoleh dari hasil kerjasama dengan orang lain. Hasil belajar diperoleh melalui sharing antar teman, 
antar kelompok, dan antar yang tahu kepada yang belum tahu. Di ruang, di kelas, sekitarnya dan semuanya adalah anggota masyarakat belajar.

5. Pemodelan (modeling)

Dalam sebuah pembelajaran keterampilan atau pengetahuan tertentu, ada model yang biasa ditiru. Model itu memberi peluang yang besar bagi guru untuk memberi contoh cara mengerjakan sesuatu, dengan begitu guru memberi model tentang bagaimana cara belajar. Sebagaian guru memberikan contoh tentang cara bekerja sesuatu, sebelum siswa melaksanakan tugas, misalnya cara menemukan kata kunci dalam bacaan. Dalam pembelajaran tersebut guru mendemonstrasikan cara menemukan kata kunci dalam bacaan dengan cara menelusuri bacaan secara tepat, dengan memanfaatkan gerak mata (scanning). Secara sederhana, kegiataan ini disebut pemodelan. Guru berperan sebagai model yang biasa ditiru dan diamati siswa, sebelum mereka berlatih menemukan kata kunci.

6. Refleksi (reflection)

Refleksi adalah cara berpikir tentang apa yang baru dipelajari atau berpikir tentang apa-apa yang sudah kita lakukan dalam hal belajar dimasa yang lalu. Siswa mengendapkan apa yang baru dipelajarinya sebagai struktur pengetahuan baru, yang merupakan pengayaan atau revisi dari pengetahuan sebelumnya. Refleksi merupakan respon terhadap kejadian, aktivitas atau pengetahuan yang baru diterima. Pada akhir pelajaran refleksi dapat dilakukan melalui pernyataan langsung tentang apa yang diperoleh hari itu, catatan atau jurnal di buku siswa, diskusi, kesan dan saran siswa mengenai pembelajaran hari itu. Melalui refleksi, siswa merasa memperoleh sesuatu yang berguna bagi dirinya tentang apa yang baru dipelajarinya, serta berfungsi sebagai umpan balik.

7. Penilaian sebenarnya (authentic assessment)

Penilaian sebenarnya adalah proses pengumpulan berbagai data yang bisa memberikan gambaran perkembangan belajar siswa. Gambaran perkembangan belajar siswa perlu diketahui oeleh guru agar bisa memastikan bahwa siswa mengalami proses pembelajaran dengan benar. Apabila data yang dikumpulkan oleh guru mengidentifikasikan bahwa siswa mengalami kemacetan dalam belajar, maka guru perlu segera mengambil tindakan 
yang tepat agar siswa terbebas dari kemacetan belajar. Karena gambaran tentang kemajuan belajar itu diperlukan disepanjang proses pembelajaran, maka asesmen tidak dilakukan di akhir periode pembelajaran atau akhir semester tetapi dilakukan bersama secara terintegrasi dalam kegiatan pembelajaran.

Menurut Aprudi (2011) ada beberapa keunggulan dari pembelajaran kontekstual adalah:

1. Pembelajaran menjadi lebih bermakna dan riil. Artinya siswa dituntut untuk dapat menangkap hubungan antara pengalaman belajar di sekolah dengan kehidupan nyata. Hal ini sangat penting, sebab dengan mengorelasikan materi yang ditemukan dengan kehidupan nyata, bukan saja bagi siswa materi itu akan berfungsi secara fungsional, akan tetapi materi yang dipelajarinya akan tertanam erat dalam memori siswa, sehingga tidak akan mudah dilupakan.

2. Pembelajaran lebih produktif dan mampu menumbuhkan penguatan konsep kepada siswa karena metode pembelajaran CTL menganut aliran konstruktivisme, dimana seorang siswa dituntun untuk menemukan pengetahuannya sendiri. Melalui landasan filosofis konstruktivisme siswa diharapkan belajar melalui "mengalami" bukan "menghafal".

3. Kontekstual adalah model pembelajaran yang menekankan pada aktivitas siswa secara penuh, baik fisik maupun mental

4. Kelas dalam pembelajaran kontekstual bukan sebagai tempat untuk memperoleh informasi, akan tetapi sebagai tempat untuk menguji data hasil temuan mereka di lapangan.

5. Materi pelajaran dapat ditemukan sendiri oleh siswa, bukan hasil pemberian dari guru.

6. Penerapan pembelajaran Kontekstual dapat menciptakan suasana pembelajaran yang bermakna.

Sedangkan kelemahan dari pembelajaran kontekstual adalah sebagai berikut:

1. Diperlukan waktu yang cukup lama saat proses pembelajaran kontekstual berlangsung.

2. Jika guru tidak dapat mengendalikan kelas maka dapat menciptakan situasi kelas yang kurang kondusif. 
3. Guru lebih intensif dalam membimbing. Karena dalam metode CTL, guru tidak lagi berperan sebagai pusat informasi. Tugas guru adalah mengelola kelas sebagai sebuah tim yang bekerja bersama untuk menemukan pengetahuan dan keterampilan yang baru bagi siswa. Siswa dipandang sebagai individu yang sedang berkembang. Kemampuan belajar seseorang akan dipengaruhi oleh tingkat perkembangan dan keluasan pengalaman yang dimilikinya. Dengan demikian, peran guru bukanlah sebagai instruktur atau "penguasa" yang memaksa kehendak melainkan guru adalah pembimbing siswa agar mereka dapat belajar sesuai dengan tahap perkembangannya.

4. Guru memberikan kesempatan kepada siswa untuk menemukan atau menerapkan sendiri ide-ide dan mengajak siswa agar dengan menyadari dan dengan sadar menggunakan strategi-strategi mereka sendiri untuk belajar. Namun dalam konteks ini tentunya guru memerlukan perhatian dan bimbingan yang ekstra terhadap siswa agar tujuan pembelajaran sesuai dengan apa yang diterapkan semula.

Berdasarkan informasi di atas, maka pembelajaran kontekstual adalah strategi pembelajaran yang menghubungkan antara materi yang diajarkan guru dengan situasi nyata siswa dan mendorong siswa membuat hubungan antara pengetahuan yang dimilikinya dengan penerapannya dalam kehidupan mereka sehari-hari. Selain itu pembelajaran kontekstual tidak mengharuskan siswa "menghafal" tetapi mengkonstruksi pengetahuan yang sudah ada pada diri siswa.

\section{Implementasi Pendidikan Karakter dalam Pembelajaran Kontekstual}

Implementasi nilai karakter dalam pembelajaran di kelas tidak diajarkan tetapi dikembangkan. Hal ini mengandung makna bahwa materi nilai budaya dan karakter bangsa bukanlah bahan ajar biasa. Sehingga, nilai-nilai itu tidak dijadikan pokok bahasan yang dikemukakan seperti mengajarkan suatu konsep, teori, prosedur, ataupun fakta seperti dalam mata pelajaran agama, bahasa indonesia, PKn, IPA, IPS, matematika dan sebagainya. Dalam mengembangkan nilai-nilai karakter guru dapat menggunakan materi pelajaran sebagai bahan atau media 
pembelajaran. Oleh karena itu, guru tidak perlu mengubah pokok bahasan yang sudah ada tetapi mengembangkan nilai-nilai budaya dan karakter bangsa. Prinsip penerapan pendidikan karakter yaitu siswa aktif dan menyenangkan (Sulistyowati, 2012). Agar kedua prinsip tersebut dapat dilaksanakan di kelas, maka perlu dipikirkan pendekatan pembelajaran yang akan digunakan. Pendidikan karakter dilaksanakan menggunakan pendekatan terintegrasi dalam semua mata pelajaran. Selain itu, pendidikan karakter diberikan secara terpadu melalui pengenalan nilai-nilai, fasilitasi kesadaran akan pentingnya nilai-nilai, dan penginternalisasian nilai-nilai kedalam tingkah laku siswa sehari-hari, baik di dalam maupun di luar kelas. Pada dasarnya, kegiatan pembelajaran, selain menjadikan siswa menguasai kompetensi (materi) yang ditargetkan, juga dirancang untuk menjadikan siswa mengenal, menyadari/peduli, dan menginternalisasi nilai-nilai dan menjadikan perilaku. Kegiatan pembalajaran dalam kerangka pengembangan karakter siswa dapat menggunakan berbagai pendekatan. Dalam tulisan ini penulis menggunakan pedekatan kontekstual sebagai konsep belajar dan mengajar yang membantu guru dan siswa mengaitkan materi yang diajarkan dengan situasi dunia nyata.

Pada setiap komponen dalam pembelajaran kontekstual memiliki karakteristik yang berbeda. Namun tujuan yang akan dicapai adalah bagaimana membentuk pengalaman belajar siswa dengan menghubungkan antara pengetahuan yang dimilikinya dengan penerapannya dalam kehidupan siswa. Hubungan antara penerapan pembelajaran kontekstual dalam upaya membentuk nilai-nilai karakter disajikan pada tabel 2 berikut ini: 
53 | al-Khwarizmi, Volume II, Edisi I, Maret 2014, Hal. 41 - 58

Tabel 2: Hubungan Pendekatan Konstektual dan Pembentukan Nilai Karakter

\begin{tabular}{|c|c|c|c|}
\hline No & $\begin{array}{l}\text { Pembelajaran } \\
\text { Konstektual }\end{array}$ & Karakteristik & $\begin{array}{l}\text { Nilai karakter yang } \\
\text { dikembangkan }\end{array}$ \\
\hline 1 & $\begin{array}{l}\text { Konstruktivisme } \\
\text { (constructivism) }\end{array}$ & $\begin{array}{l}\text { Pembelajaran hendaknya dikemas } \\
\text { menjadi proses 'mengkontruksi' bukan } \\
\text { 'menerima' pengetahuan. Siswa } \\
\text { membangun sendiri pengetahuan mereka } \\
\text { melalui keterlibatan aktif dalam proses } \\
\text { belajar mengajar. Siswa menjadi pusat } \\
\text { kegiatan, bukan guru. Pembelajaran } \\
\text { dirancang dalam bentuk siswa bekerja, } \\
\text { praktik mengerjakan sesuatu, berlatih } \\
\text { secara fisik, menulis karangan, } \\
\text { mendemonstrasikan, menciptakan } \\
\text { gagasan. }\end{array}$ & $\begin{array}{l}\text { - Berfikir kritis dan } \\
\text { logis } \\
\text { - Rasa ingin tahu } \\
\text { - Toleransi } \\
\text { - Bertanggung jawab }\end{array}$ \\
\hline 2 & $\begin{array}{l}\text { Bertanya } \\
\text { (questioning) }\end{array}$ & $\begin{array}{l}\text { Siswa belajar mengajukan pertanyaan } \\
\text { tentang fenomena, bagaimana menyusun } \\
\text { pertanyaan yang dapat diuji, dan belajar } \\
\text { untuk saling bertanya tentang bukt, } \\
\text { interpretasi, dan penjelasan }\end{array}$ & $\begin{array}{l}\text { - Berfikir kritis dan } \\
\text { logis } \\
\text { - Rasa ingin tahu } \\
\text { - Mandiri } \\
\text { - Kreatif }\end{array}$ \\
\hline 3 & $\begin{array}{l}\text { Menemukan } \\
\text { (inquiry) }\end{array}$ & $\begin{array}{l}\text { Siswa belajar menggunakan keterampilan } \\
\text { berfikir kritis saat mereka berdiskusi dan } \\
\text { menganalisis bukti, mengevaluasi ide dan } \\
\text { proposisi, merefleksi validitas data, } \\
\text { memproses, membuat kesimpulan. } \\
\text { Kemudian menentukan bagaimana } \\
\text { mempresentasikan dan menjelaskan } \\
\text { penemuannya, dan menghubungkan ide- } \\
\text { ide atau teori untuk mendapatkan konsep. }\end{array}$ & $\begin{array}{l}\text { - Berfikir kritis dan } \\
\text { logis } \\
\text { - Rasa ingin tahu } \\
\text { - Toleransi } \\
\text { - Kreatif }\end{array}$ \\
\hline 4 & $\begin{array}{l}\text { Masyarakat } \\
\text { belajar (learning } \\
\text { community) }\end{array}$ & $\begin{array}{l}\text { Semua siswa harus mempunyai } \\
\text { kesempatan untuk bicara dan berbagi ide, } \\
\text { mendengarkan ide siswa lain dengan } \\
\text { cermat, dan bekerja sama untuk } \\
\text { membangun pengetahuan dengan teman } \\
\text { di dalam kelompoknya. }\end{array}$ & $\begin{array}{l}\text { - Demokratis } \\
\text { - Peduli sosial } \\
\text { - Tanggung jawab } \\
\text { - Toleransi }\end{array}$ \\
\hline 5 & $\begin{array}{l}\text { Pemodelan } \\
\text { (modeling) }\end{array}$ & $\begin{array}{l}\text { Proses penampilan suatu contoh agar } \\
\text { siswa befikir, bekerja dan belajar. }\end{array}$ & $\begin{array}{l}\text { - Tanggung jawab } \\
\text { - Rasa ingin tahu } \\
\text { - Mandiri } \\
\end{array}$ \\
\hline 6 & \begin{tabular}{|l|} 
Refleksi \\
(reflection)
\end{tabular} & $\begin{array}{l}\text { Siswa menelaah suatu kejadian, } \\
\text { kegiatan, pengalaman serta berpikir } \\
\text { tentang apa yang dipelajari, bagaimana }\end{array}$ & $\begin{array}{l}\text { - Tanggung jawab } \\
\text { - Rasa ingin tahu } \\
\text { - Mandiri }\end{array}$ \\
\hline
\end{tabular}


Implementasi Pendidikan Berkarakter ... 54

\begin{tabular}{|l|l|l|l|}
\hline & & $\begin{array}{l}\text { merasakan dan bagaimana } \\
\text { menggunakan pengetahuan baru } \\
\text { tersebut. }\end{array}$ & \\
\hline 7 & $\begin{array}{l}\text { Penilaian } \\
\text { sebenarnya } \\
\text { (authentic } \\
\text { assessment) }\end{array}$ & $\begin{array}{l}\text { Siswa dapat mendemonstrasikan } \\
\text { kemampuannya untuk menyelesai } \\
\text { kan tugas-tugas, memecahkan masalah, } \\
\text { atau mengekspresikan pengetahuannya } \\
\text { dengan cara mensimulasikan situasi yang } \\
\text { dapat ditemui didalam dunia nyata di luar } \\
\text { lingkungan sekolah. }\end{array}$ & $\begin{array}{l}\bullet \text { Tujur } \\
\bullet \text { Disiplin } \\
\text { - Menghargai karya\& } \\
\text { prestasi orang lain }\end{array}$ \\
\hline
\end{tabular}

(Sumber: Sulistyowati, 2012)

Pembelajaran konstektual mencakup beberapa strategi yaitu 1) pembelajaran berbasis masalah, 2) pembelajaran kooperatif, 3) pembelajaran berbasis proyek, 4) pembelajaran pelayanan, dan 5) pembelajaran berbasis kerja. Kelima strategi tersebut dapat memberikan nurturant effect pengembangan karakter siswa seperti cerdas, terbuka, tanggung jawab, dan rasa ingin tahu (Sulistyowati, 2012).

Implementasi pendidikan karakter dalam pembelajaran melalui pendekatan kontekstual dapat dilihat pada Rencana Pelaksanaan Pembelajaran (RPP). RPP merupakan rencana yang menggambarkan prosedur dan pengorganisasian pembelajaran untuk mencapai satu kompetensi dasar yang ditetapkan dalam standar isi dan telah dijabarkan dalam silabus. Lingkup RPP paling luas mencakup 1 (satu) kompetensi dasar yang terdiri dari 1(satu) atau beberapa indikator untuk 1 (satu) kali pertemuan atau lebih. RPP disusun berdasarkan silabus yang telah dikembangkan oleh sekolah. RPP secara umum tersusun atas SK, KD, tujuan pembelajaran, materi pembelajaran, metode pembelajaran, langkah-langkah pembelajaran, sumber belajar, dan penilaian. Di bawah ini penulis mencoba memberikan contoh alternatif penerapan pendidikan karakter dalam pembelajaran matematika melalui pendekatan kontektual melalui RPP sebagai berikut: 
55 | al-Khwarizmi, Volume II, Edisi I, Maret 2014, Hal. 41 - 58

Rencana Pelaksanaan Pembelajaran (RPP)

Mata Pelajaran : Matematika

Kelas/Semester : VII/1

Pokok Bahasan : Sifat-sifat Bangun Ruang

Sub Pokok Bahasan : Sifat-sifat Kubus

Alokasi Waktu

: 2 x 40 Menit (2 Jam Pelajaran)

A. Standar Kompetensi:

Menentukan sifat bangun ruang dan hubungan antar bangun

B. Kompetensi Dasar:

Mengidentifikasi sifat-sifat bangun ruang

C. Indikator:

Mengidentifikasi sifat-sifat kubus

D. Materi Pokok:

Sifat-sifat kubus

E. Tujuan pembelajaran:

- Siswa dapat menuliskan sifat-sifat kubus dengan benar

- Siswa dapat menyebutkan sifat-sifat kubus dengan benar

- Siswa dapat menyimpulkan sifat-sifat kubus dengan benar

F. Pendekatan Pembelajaran:

CTL (Contextual Teaching and Learning)

G. Media pembelajaran:

Model kubus

H. Kegiatan Pembelajaran

1. Kegiatan Awal (10 menit)

- Guru membuka pelajaran

- Guru mengkondisikan kelas dan siswa pada situasi belajar yang konduksif

- Guru mengadakan apersepsi, sebagai penggalian pengetahuan awal siswa terhadap materi yang diajarkan.

- Dengan mengajukan pertanyaan kepada siswa "masih ingatkah kalian termasuk bentuk bangun ruang apakah benda ini?"

- Guru menyampaikan tujuan pembelajaran

- Guru membagi siswa menjadi 5 kelompok, masingmasing kelompok 4-5 orang 
- Guru membagikan sebuah model kubus dan LKS pada setiap kelompok.

2. Kegiatan Inti (60 menit)

\begin{tabular}{|c|c|c|c|}
\hline $\begin{array}{c}\text { Tahap } \\
\text { Pembelajaran } \\
\text { Kontekstual }\end{array}$ & Kegiatan Guru & Kegiatan Siswa & $\begin{array}{c}\text { Nilai Karakter } \\
\text { yang } \\
\text { Dikembangkan }\end{array}$ \\
\hline $\begin{array}{l}\text { 1. Tahap } \\
\text { kontrukstivis } \\
\text { me, inkuiri } \\
\text { dan } \\
\text { pemodelan }\end{array}$ & $\begin{array}{l}\text { Menugaskan siswa } \\
\text { berdiskusi } \\
\text { kelompok untuk } \\
\text { mengamati dan } \\
\text { memanipulasi } \\
\text { model kubus, serta } \\
\text { menentukan sifat- } \\
\text { sifat kubus }\end{array}$ & $\begin{array}{l}\text { Berdiskusi } \\
\text { kelompok dengan } \\
\text { mengamati dan } \\
\text { memanipulasi } \\
\text { model kubus, serta } \\
\text { menentukan sifat- } \\
\text { sifat kubus sesuai } \\
\text { petunjuk LKS. }\end{array}$ & $\begin{array}{l}\text { - } \text { Berfikir kritis } \\
\text { dan logis } \\
\text { - Rasa ingin tahu } \\
\text { - Toleransi } \\
\text { - Tanggungjawab } \\
\text { - Kreatif } \\
\text { - Mandiri }\end{array}$ \\
\hline $\begin{array}{l}\text { 2. Tahap } \\
\text { bertanya }\end{array}$ & $\begin{array}{l}\text { Menjawab } \\
\text { pertanyaan siswa } \\
\text { tentang sifat-sifat } \\
\text { kubus }\end{array}$ & $\begin{array}{l}\text { Bertanya jawab } \\
\text { dengan guru } \\
\text { mengenai hasil } \\
\text { pengamatan dan } \\
\text { manipulasi model } \\
\text { kubus tentang sifat- } \\
\text { sifat kubus }\end{array}$ & $\begin{array}{l}\text { - Berpikir kritis } \\
\text { dan logis } \\
\text { - Rasa ingin tahu } \\
\text { - Mandiri } \\
\text { - Kreatif }\end{array}$ \\
\hline $\begin{array}{l}\text { 3. Tahap } \\
\text { masyarakat } \\
\text { belajar }\end{array}$ & $\begin{array}{l}\text { - Menugaskan } \\
\text { perwakilan } \\
\text { kelompok untuk } \\
\text { melaporkan hasil } \\
\text { diskusi } \\
\text { kelompoknya } \\
\text { dalam } \\
\text { mengidentifikasi } \\
\text { sifat-sifat kubus di } \\
\text { depan kelas } \\
\text { - Menugaskan } \\
\text { kelompok yang } \\
\text { tidak melaporkan } \\
\text { untuk menanggapi } \\
\text { dengan bertanya } \\
\text { dan memberi } \\
\text { komentar }\end{array}$ & $\begin{array}{l}\text { - Perwakilan } \\
\text { kelompok } \\
\text { melaporkan hasil } \\
\text { diskusi dalam } \\
\text { mengidentifikasi } \\
\text { sifat-sifat kubus di } \\
\text { depan kelas } \\
\text { - Kelompok yang } \\
\text { tidak melaporkan } \\
\text { hasil diskusi, } \\
\text { menanggapi } \\
\text { dengan bertanya } \\
\text { dan memberi } \\
\text { komentar }\end{array}$ & $\begin{array}{l}\text { - Demokratis } \\
\text { - Peduli sosial } \\
\text { - Tanggung } \\
\text { jawab } \\
\text { - Toleransi }\end{array}$ \\
\hline $\begin{array}{l}\text { 4. Tahap } \\
\text { pemodelan }\end{array}$ & $\begin{array}{l}\text { Memberi peragaan } \\
\text { cara yang benar } \\
\text { mengamati dan } \\
\text { memanipulasi }\end{array}$ & $\begin{array}{l}\text { Menyimak guru } \\
\text { yang } \\
\text { memperagakan } \\
\text { cara yang benar, }\end{array}$ & $\begin{array}{l}\text { - Rasa ingin tahu } \\
\text { - Tanggung } \\
\text { jawab } \\
\text { - Mandiri }\end{array}$ \\
\hline
\end{tabular}


57 | al-Khwarizmi, Volume II, Edisi I, Maret 2014, Hal. 41 - 58

\begin{tabular}{|c|c|c|c|}
\hline & $\begin{array}{l}\text { model kubus dalam } \\
\text { mengidentifikasi } \\
\text { sifat-sifat kubus }\end{array}$ & $\begin{array}{l}\text { mengamati, dan } \\
\text { memanipulasi } \\
\text { model kubus dalam } \\
\text { mengidentifikasi } \\
\text { sifat-sifat kubus }\end{array}$ & \\
\hline $\begin{array}{l}\text { 5. Tahap } \\
\text { refleksi }\end{array}$ & $\begin{array}{l}\text { Menugaskan siswa } \\
\text { mengaitkan } \\
\text { pembelajaran } \\
\text { kedalam kehidupan } \\
\text { sehari-hari dengan } \\
\text { cara menyebutkan } \\
\text { sisfat-sifat kubus \& } \\
\text { menunjukkannya } \\
\text { pada benda di kelas } \\
\text { yang termasuk } \\
\text { bangun kubus. }\end{array}$ & $\begin{array}{l}\text { Mengaitkan } \\
\text { pembelajaran } \\
\text { kedalam kehidupan } \\
\text { sehari-hari dengan } \\
\text { cara menyebutkan } \\
\text { sifat-sifat kubus dan } \\
\text { menunjukannya } \\
\text { pada benda yang } \\
\text { ada di kelas yang } \\
\text { termasuk bangun } \\
\text { kubus }\end{array}$ & $\begin{array}{l}\text { - Rasa ingin tahu } \\
\text { - Tanggung } \\
\text { jawab } \\
\text { - Mandiri }\end{array}$ \\
\hline
\end{tabular}

3. Kegiatan Akhir (10 menit)

- Guru bersama siswa membahas kesimpulan pembelajaran

- Guru menutup pelajaran.

I. Tahap Penilaian

- Kognitif: Guru dapat mengunakan asesmen untuk melihat proses perkembangan belajar siswa dan dapat menggunakan tes.

- Afektif: Guru dapat melihat sikap siswa saat proses pembelajaran dan mengerjakan tugas (untuk pengecekan nilai karakter)

- Psikomotorik: Guru menilai dari presentasi hasil duskusi dan keterampilan dalam menggunakan model kubus

J. Sumber Pustaka

\section{Penutup}

Pendidikan karakter merupakan pendidikan yang mengembangkan nilai-nilai budaya dan karakter bangsa pada diri siswa, sehingga mereka memiliki dan menerapkan nilai-nilai tersebut dalam kehidupan dirinya sebagai anggota masyarakat dan warga negara yang religius, produktif, dan kreatif. Implementasi pendidikan karakter dapat dikembangkan di sekolah melalui pengalaman belajar dan proses pembelajaran yang bermuara pada pembentukan karakter dalam diri siswa. Pada dasarnya kegiatan 
pembelajaran matematika, selain menjadikan siswa menguasai kompetensi (materi) yang ditargetkan, juga dirancang untuk menjadikan siswa mengenal, menyadari/peduli, dan menginternalisasi nilai-nilai dan menjadikan perilaku. Nilai-nilai karakter yang dapat dikembangkan adalah berfikir kritis dan logis, rasa ingin tahu, toleransi, bertanggung jawab, mandiri, kreatif, jujur, menghargai karya dan prestasi orang lain, dan disiplin. Kegiatan pembelajaran matematika dalam kerangka pengembangan karakter siswa dapat menggunakan berbagai pendekatan. Diantaranya pendekatan kontekstual sebagai konsep belajar dan mengajar yang membantu guru dan siswa mengaitkan antara materi yang diajarkan, dengan situasi dunia nyata. Sehingga, siswa mampu untuk membuat hubungan antara pengetahuan yang dimilikinya dengan penerapannya dalam kehidupan siswa. Dengan adanya kajian di atas diharapkan dapat menjadi alternatif penerapan pembelajaran yang berbasis karakter dan dapat dikembangkan pada metode pembelajaran yang lainnya.

\section{DAFTAR PUSTAKA}

Aprudin. 2011. Penerapan Pembelajaran Kontekstual, Keunggulan dan Kelemahan Pembelajaran Kontekstual. Blogspot: diakses tanggal 9 Juni 2012.

Budimansyah, Darsim. 2010. Model Pendidikan Karakter di Perguruan Tinggi. Bandung: Universitas Pendidikan Indonesia.

Bukit, Seriwati. 2012. Pendidikan Karakter. Medan: Kementerian Agama.

Kementerian Pendidikan Nasional. 2010. Pengembangan

Pendidikan Budaya dan Karakter Bangsa. Jakarta:

Balitbang.

Nurhadi. 2004. Kurikulum 2004. Jakarta: PT Gramedia Widiasarana Indonesia.

\section{Permendiknas}

Sulistyowati, Endah. 2012. Implementasi Kurikulum Pendidikan Karakter. Yogjakarta: PT Citraaji Parama. Undang-Undang Republik Indonesia No.20 Tahun 2003 tentang Sistem Pendidikan Nasional. 